\title{
Aplikasi Level Biochar dan Jarak Tanam terhadap Pertumbuhan dan Produksi Rumput Raja (Pennisetum purpuphoides)
}

Adam H. L. Moruk ${ }^{\mathrm{a}}$ dan Oktovianus R. Nahak T. B. ${ }^{\mathrm{b}}$

${ }^{a}$ Fakultas Pertanian, Universitas Timor, Kefamenanu, TTU - NTT, Indonesia, email: morukadam628@gmail.com

${ }^{b}$ Fakultas Pertanian, Universitas Timor, Kefamenanu, TTU - NTT, Indonesia, email: oktovianusrafael@yahoo.co.id

\section{Article Info}

Article history:

Received 12 Desember 2019

Received in revised form 20 April 2019

Accepted 14 Desember 2019

DOI:

https://doi.org/10.32938/ja.v5i1.908

Keywords:

Biochar

Jarak tanam

Rumput raja

\begin{abstract}
Abstrak
Tujuan dari penelitian ini adalah untuk mendapatkan level biochar pada pertumbuhan dan produksi rumput raja dengan jarak tanam terbaik serta interaksi antara level biochar dan pengaturan pada pertumbuhan dan produksi rumput raja. Penelitian dilaksanakan di lahan percobaan Fakultas Pertanian Universitas Timor, Kelurahan Sasi, Kecamatan Bikomi Selatan, Kabupaten Timor Tengah Utara, Penelitian berlangsung selama 48 hari atau selama 1 masa produksi. Tiap masa produksi berlangsung selama 48 HST. Metode yang digunakan dalam penelitian ini adalah metode eksperimen, menggunakan Rancangan Acak Lengkap (RAL) pola faktorial 3x3. Adapun faktor yang di uji yaitu faktor pertama level biochar dan faktor kedua adalah jarak tanam dan tiap kombinasi percobaan diulang sebanyak 3 kali. Variabel yang diamati dalam penelitian ini yaitu tinggi tanaman, jumlah anakan, jumlah daun, berat segar daun dan berat kering daun. Data di analisis dengan analisis sidik ragam (Anova) sesuai rancangan yang digunakan. Analisis data menggunakan software SAS versi 9.1. Hasil menunjukkan bahwa adanya interaksi antara perlakuan dosis biochar dan jarak tanam terhadap pertumbuhan tinggi tanaman rumput raja, namun untuk variabel lainnya tidak terjadi interaksi. Disimpulkan bahwa level biochar dalam peningkatan pertumbuhan rumput raja bervariasi, untuk tinggi tanaman dan jumlah anakan tanpa menggunakan biochar masih dapat bertumbuh secara optimal sedangkan untuk peningkatan jumlah daun pada penggunaan level $250 \mathrm{~g} / \mathrm{lubang}$ tanam. Level $500 \mathrm{~g} / \mathrm{lubang}$ tanam efektif dalam meningkatkan berat kering dan berat segar daun rumput raja. Jarak tanam terbaik pada pertumbuhan dan produksi rumput raja bervariasi untuk tinggi tanaman dan jumlah anakan jarak tanam terbaik adalah $20 \mathrm{~cm}$ sedangkan untuk peningkatan jumlah daun terbanyak pada jarak tanam $40 \mathrm{~cm}$. Jarak tanam 60 $\mathrm{cm}$ efektif dalam meningkatkan berat kering dan berat segar daun rumput raja serta adanya interaksi antara level biochar dan jarak tanam pada tinggi tanaman sedangkan pada variabel lain tidak ada interaksi.
\end{abstract}

\section{Pendahuluan}

Hijauan merupakan pakan dasar ternak ruminansia yang bermanfaat untuk kebutuhan pokok dan kebutuhan produksi seekor ternak. Sebagai pakan dasa ternak, rumput diberikan dengan porsi dalam jumlah besar sehingga dituntut ketersediaan dalam produksi yang tinggi dan kandungan nutrisi yang memadai. Permasalahan ketersediaan rumput sebagai pakan ternak dilahan kering sampai saat ini masih menjadi problem tersendiri bagi masyarakat peternak di wilayah Nusa Tenggara Timur secara umum dan di Kabupaten Timor Tengah Utara (TTU) khususnya, dimana produktivitas rumput alam maupun budidaya mengalami penurunan yang ditandai dengan rendahnya ketersediaan rumpu pada musim kemarau sehingga ternak mengalami penurunan bobot badan akibat tidak tercukupinya pakan hijauan dari sisi kualitas maupun kuantitasnya.

Rumput yang sangat potensial dan sering diberikan pada ternak ruminansia adalah rumput raja (Pennisetum purpuphoiedes). Rumput in merupakan hasil persilangan antara rumput gajah (Pennisetum purpureum) dengan rumput barja (Pennisetum thypoiedes). Rumput raja adalah tanaman tahunan (perennial), tumbuh tegak membentuk rumpun dengan perakaran yang dalam, bentuknya mirip dengan tanaman tebu, tingginya $2-4 \mathrm{~m}$ dan apabila dibiarkan tumbuh tegak dapat mencapai $7 \mathrm{~m}$, berbatang tebal dan keras. Rumpu raja memiliki pertumbuhan yang sangat cepat mengalahkan rumput gajah Produksi rumput raja sangat tinggi dapat mencapai 1.076 ton rumput segar/ha/tahun (Suyitman, 2014)

Produktivitas rumput dilahan kering perlu mendapat perhatian khusus, hal ini karena karakter lahan kering seperti intensitas cahaya yang sangat tinggi, suhu lingkungan dan evapotranspirasi yang tinggi serta kesuburan lahan menjad faktor pembatas dalam pertumbuhan dan produksi tanaman, untuk itu dibutuhkan aplikasi teknologi yang tepat melalui teknik pemupukan yang sesuai dengan kondisi iklim yang ada sehingga dapat mendukung produktivitas tanaman. Biochar merupakan salah satu teknologi sederhana dan bersifat ramah lingkungan dan juga merupakan butiran halus substansi arang kayu yang porous, bila digunakan sebagai suatu pembenah tanah dapat mengurangi $\mathrm{CO}_{2}$ dari udara (Gani, 2009). Dalam tanah, biochar menyediakan habitat bagi mikroorganisme tanah. Bila digunakan sebagai pembenah tanah bersama pupuk anorganik dan inorganik, biochar dapat meningkatkan produktivitas serta retensi dan ketersediaan hara bagi tanaman. Aplikasi biochar dapat menurunkan kepadatan tanah, kekuatan tanah, Al dapat dipertukarkan dan $\mathrm{Fe}$ dan meningkatkan porositas, kandungan air tanah tersedia, $\mathrm{C}$-organik, $\mathrm{P}$ tersedia, $\mathrm{K}$ dapa dipertukarkan dan $\mathrm{Ca}$ dapat dipertukarkan. Atas dasar itu diperlukan inovasi untuk memperbaiki kualitas dan kesehatan tanah melalui pemanfaatan sekam sebagai sumber daya lokal yang melimpah untuk diproduksi sebagai biochar (Steiner et al., 2007).

Faktor lingkungan yang dapat mempengaruhi pertumbuhan dan produksi rumput raja salah satunya pengaturan jarak tanam. Pengaturan jarak tanam perlu diatur supaya tidak mengganggu pertumbuhan rumput raja. Pertumbuhan dan produksi rumput raja diduga akan berbeda jika menggunakan jarak tanam yang berbeda, karena jarak tanam akan mempengaruhi kompetisi antar tanaman. Kompetisi atau persaingan ini terjadi untuk mendapatkan kebutuhan masingmasing rumput seperti sinar matahari, air, nutrisi, ruang tumbuh dan $\mathrm{CO}_{2}$.

Pengaturan jarak tanam yang tepat dapat meningkatkan pertumbuhan yang cepat dan produksi yang tinggi. Pengaturan jarak tanam untuk mendapatkan produksi yang optimum perlu diperhatikan kerapatan tanaman dengan pengaturan jarak tanam sehingga pemanfaatan sumber daya lingkungan dapa dimanfaatkan secara maksimal. Pada sistem bercocok tanam, apabila kerapatan tanaman melebihi batas optimum, maka terjadi hambatan pertumbuhan tanaman akibat persaingan dengan tanaman lain. Semakin dekat jarak tanaman antara satu tanaman dengan tanaman lain, maka persaingan antar tanaman semakin besar dalam menerima sinar matahari, air dan unsur hara. Penelitian ini bertujuan untuk mengetahui level biochar terbaik pada pertumbuhan dan produksi rumput raja dan jarak tanam terbaik pada pertumbuhan dan produksi rumput raja serta interaksi antara level biochar dan jarak tanam pada pertumbuhan dan produksi rumput raja

\section{Metode}

\subsection{Lokasi dan Waktu Penelitian}

Penelitian ini dilaksanakan di lahan percobaan Fakultas Pertanian Universitas Timor, Kelurahan Sasi, Kecamatan Bikomi Selatan, Kabupaten Timor Tengah Utara, Penelitian berlangsung selama 48 hari atau selama 1 masa produksi.

\subsection{Alat dan Bahan}

Adapun peralatan yang digunakan adalah linggis, sekop, parang, ember, pengayak tanah, timbangan, mistar, oven listrik dan alat tulis menulis dan bahannya terdiri dari stek rumput raja 243 batang, lahan seluas $54 \mathrm{~m}^{2}$ di dalamnya terdapat 27 bedeng percobaan dimana tiap-tiap bedeng berukuran $2 \times 2$ meter, pupuk biochar dengan bahan dasar sekam padi.

\subsection{RancanganPenilitian}

Metode yang digunakan dalam penelitian ini adalah metode eksperimen, menggunakan Rancangan Acak Lengkap (RAL) pola faktorial 3x3. Adapun faktor yang di uji yaitu faktor pertama level biochar (B) dan faktor kedua adalah jarak tanam $(\mathrm{J})$

Faktor I. level biochar terdiri dari 3 taraf meliputi :

$\mathrm{B}_{0} \quad$ : Tanpa Biochar

$\mathrm{B}_{1}$ : Biochar $250 \mathrm{~g} /$ lubang tanam

$\mathrm{B}_{2}$ : Biochar $500 \mathrm{~g} /$ lubang tanam

Faktor II. jarak tanam terdiri dari 3 tarafmeliputi :

$\mathrm{J}_{0} \quad$ : Jarak tanam $20 \mathrm{~cm}$

$\mathrm{J}_{1} \quad$ : Jarak tanam $40 \mathrm{~cm}$

$\mathrm{J}_{2} \quad$ : jarak tanam $60 \mathrm{~cm}$

Dari kedua faktor diatas dihasilkan 9 kombinasi perlakuan yang terdiri dari : $\mathrm{B}_{0} \mathrm{~J}_{0}$ $\mathrm{B}_{0} \mathrm{~J}_{1}, \mathrm{~B}_{0} \mathrm{~J}_{2}, \mathrm{~B}_{1} \mathrm{~J}_{0}, \mathrm{~B}_{1} \mathrm{~J}_{1}, \mathrm{~B}_{1} \mathrm{~J}_{2}, \mathrm{~B}_{2} \mathrm{~J}_{0}, \mathrm{~B}_{2} \mathrm{~J}_{1}, \mathrm{~B}_{2} \mathrm{~J}_{2}$ dari tiap kombinasi percobaan diulang sebanyak 3 kali.

\subsection{Prosedur Penelitian}

1. Persiapan lahan diawali dengan melakukan pengolahan lahan yaitu dengan membersihkan dan melakukan pembalikan tanah.

2. Lahan yang telah diolah selanjutnya dibuat dalam bentuk beden dan tiap beden berukuran $2 \times 2 \mathrm{~m}$ dan dibuat lubang dengan kedalaman $\pm 10 \mathrm{~cm}$, tiap petak berisi 9 lubang tanama. Jarang antar lubang tanam dibuat sesuai dengan perlakuan.

\section{Pembuatan Biochar}

Proses pembuatan biochar mengikuti petunjuk (Djaenudin, 2007):

1. Sekam di masukan kedalam drum setengah bagian sambil di padatkan dan diberi sedikit minyak tanah lalu bakar dengan memasukan api kedalam pipa yang berada dalam drum

2. Sekam diisi dalam ke dalam drum sampai terisi penuh

3. Kemudian sekam di bakar melalui lubang silindris

4. Sekam yang terbakar sedikit demi sedikit akan jatuh ke bawah sambil di balik-balik sehingga menjadi arang sekam. 
5. Arang sekam yang telah berwarna hitam di keluarkan menggunakan sekop

6. Arang sekam di siram dengan air bersih agar arang sekam tidak menjadi abu

7. Menjemur arang sekam supaya kering, kemudian masukan kedalam karung atau plastik dan siap di gunakan.

\subsection{Inkubasi Media}

Sebelum dilakukan penanaman, terlebih dahulu media tanam diinkubasi selama 1 minggu. Tiap lubang tanam diisi dengan biochar sesuai perlakuan dan selanjutnya dibiarkan selama 3 hari sebelum ditanam. Inkubasi bertujuan untuk memberikan kesempatan agar mikroorganisme pengurai tanah dapat hidup dan menyesuaikan dengan lingkungan tanah.

\subsection{Penanaman}

Penanaman dilakukan dengan menempatkan stek rumput raja yang terlebih dahulu dipotong dengan ukuran $20 \mathrm{~cm}$. Tiap lubang tanam diisi sebanyak 2 stekan rumput raja. Selanjutnya, tanaman dibiarkan bertumbuh selama 2 minggu untuk dilakukan trimming (pemangkasan).

\subsection{Pemeliharaan Tanaman Rumput raja}

Pada stadium awal pertumbuhan, rumput raja perlu mendapatkan air yang cukup. Oleh karena itu, penyiraman dilakukan secara rutin satu sampai dua kali sehari (pagi dan sore), atau tergantung cuaca dan keadaan tanah.

\subsection{Pengambilan Data}

Pengambilan data tinggi tanaman, jumlah anakan, jumlah daun diamat pada tiap 7 hari sedangkan data berat segar dan kering daun diperoleh pada akhir masa penelitian.

\subsection{Variabel Penelitian}

\subsubsection{Tinggi Tanaman $(\mathbf{c m})$}

Tinggi tanaman diukur titik tumbuh hingga daun yang paling tertinggi dengan menggunakan meter. Tinggi tanaman diukur satu minggu setelah trimming/pemangkasan kemudian dilakukan perhitungan rataan tinggi tanaman.

$$
\frac{\mathrm{TT}=\mathrm{TT} 1+\mathrm{TT} 2+\mathrm{TT} 3+\mathrm{TT} 4}{\mathrm{~T}}
$$

Keterangan:

TT1 = Tinggi tanaman pengukuran pertama

TT2 $=$ Tinggi tanaman pengukuran kedua

TT3 = Tinggi tanaman pengukuran ketiga

TT4 $=$ Tinggi tanaman pengukuran keempat

$\mathrm{T}=$ Waktu (Minggu

\subsubsection{Jumlah Anakan (tunas)}

Jumlah anakan diukur dengan cara menghitung setiap anakan yang tumbuh setiap minggunya kemudian dilakukan perhitungan rataan jumlah anakan.

$\frac{\mathrm{JA}=\mathrm{JA} 1+\mathrm{JA} 2+\mathrm{JA} 3+\mathrm{JA} 4}{\mathrm{~T}}$

Keterangan:

JA1 = Jumlah anakan pengkuran pertama

JA2 = Jumlah anakan pengkuran kedua

JA3 = Jumlah anakan pengukuarn ketiga

JA4 = Jumlah anakan pengukuran keempat

$\mathrm{T}=$ Waktu (hari)

\subsubsection{Jumlah Daun ( helai)}

Jumlah dauan dihitung dan mengamati banyaknya helai daun yang baru tumbuh pada stek

$$
\frac{\mathrm{JD}=\mathrm{JD} 1+\mathrm{JD} 2+\mathrm{JD} 3+\mathrm{JD} 4}{\mathrm{~T}}
$$

Keterangan:

JD1 = Jumlah daun pengukuran pertama

JD2 = Jumlah daun pengukuran kedua

JD3 $=$ Jumlah daun pengukuran ketiga

JD4 = Jumlah daun pengukuran keempat

$\mathrm{T}=$ Waktu (minggu)

\subsubsection{Berat Segar Daun (g)}

Berat segar daun diukur dengan cara penimbangan pada masa produksi pertama 48 hari setelah di tanam.

$\underline{\mathrm{BSD}}=\mathrm{BSD} 1+\mathrm{BSD} 2+\mathrm{BSD} 3+\mathrm{BSD} 4$

$$
\mathrm{T}
$$

Keterangan:

BSD1 = Berat segar daun pengukuran pertama

BSD2 = Berat segar daun pengukuran kedua

BSD3 $=$ Berat segar daun pengukuran ketiga

BSD4 = Berat segar daun pengukuran keempat

$\mathrm{T}=$ Waktu (minggu)

\subsubsection{Berat Kering Daun (g)}

Berat kering daun diukur dengan cara penimbangan pada rumput yang sudah dikeringkan di dalam oven selama 48 jam dengan suhu $70^{\circ} \mathrm{C}$.

$\underline{\mathrm{BKD}}=\mathrm{BKD} 1+\mathrm{BKD} 2+\mathrm{KKD} 3+\mathrm{BKD} 4$

Keterangan:

$\mathrm{BKD} 1=$ Berat kering daun pengukuran pertama

$\mathrm{BKD} 2=$ Berat kering daun pengukuran kedua

$\mathrm{BKD} 3=$ Berat kering daun pengukuran ketiga

BKD4 = Berat kering daun pengukuran keempat

$\mathrm{T} \quad=$ Waktu (minggu).

\subsection{Analisis Data}

Data di analisis dengan analisis sidik ragam (Anova) sesuai rancangan yang digunakan. Analisis data menggunakan software SAS versi 9.1

\section{Hasil dan Pembahasan}

\subsection{Tinggi tanaman}

Tinggi tanaman merupakan salah satu parameter yang digunakan untuk mengetahui pertumbuhan vegetatif tanaman. Proses pertumbuhan tersebut tentunya dipengaruhi oleh beberapa faktor yaitu diantaranya lingkungan, fisiologis dan genetika tanaman. Menurut Sitompul dan Guritno (1995), tinggi tanaman merupakan ukuran tanaman yang sering diamati baik sebagai indikator pertumbuhan maupun sebagai parameter yang digunakan untuk mengukur pengaruh lingkungan atau perlakuan yang diterapkan. Data tinggi tanaman rumput yang di beri perlakuan kombinasi biochar serta jarak tanam berbeda tersaji pada Gambar 1

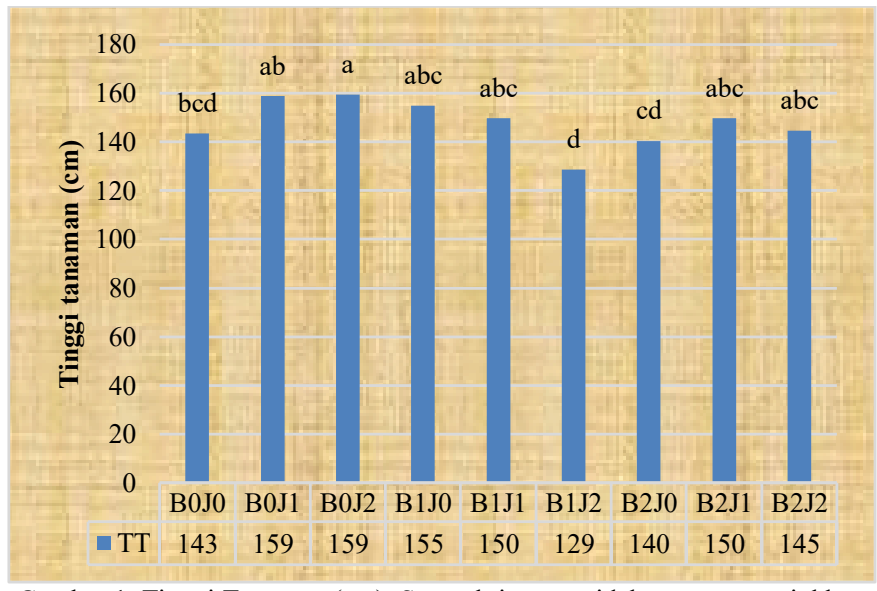

Gambar 1. Tinggi Tanaman (cm); Superskrip yang tidak sama menunjukkan berbeda nyata $(\mathrm{P}<0,05)$; Tidak Terjadi Interaksi Antara Faktor

Hasil penelitian menunjukkan bahwa tanaman tertinggi pada perlakuan $\left(\mathrm{B}_{0} \mathrm{~J}_{2}\right)=159 \mathrm{~cm}$ dan tinggi tanaman terendah pada perlakuan $\left(\mathrm{B}_{1} \mathrm{~J}_{2}\right)=129 \mathrm{~cm}$ Hasil sidik ragam (Anova) menunjukkan bahwa terjadi interaksi $(\mathrm{P}<0.05)$ antara perlakuan dosis biochar dan jarak tanam terhadap pertumbuhan tinggi tanaman rumput raja. Hal ini menggambarkan bahwa perlakuan biochar pada tanaman rumput raja dapat bertumbuh secara optimal demikian pula pada jarak tanam 20 $\mathrm{cm}$ efektif dan efisien dalam menunjang pertumbuhan tanaman. Uji duncan menunjukkan bahwa hanya pada pasangan perlakuan $\mathrm{B}_{1} \mathrm{~J}_{0}, \mathrm{~B}_{1} \mathrm{~J}_{1}, \mathrm{~B}_{2} \mathrm{~J}_{1}$, dan $\mathrm{B}_{2} \mathrm{~J}_{2}$. yang tidak berbeda nyata. Hal ini berkaitan dengan kemampuan dan kelebihan dari rumput raja itu sendiri. Salah satu kelebihan rumput raja adalah memiliki daya adaptasi yang sangat luas mulai dari jenis tanah tekstur ringan, sedang sampai berat dan tanah yang kurang subur serta dikelola dengan kurang baik rumput raja masih tetap menghasilkan hijauan yang tinggi. Tidak terlalu berbeda antara rumput raja dan rumput gajah, dimana menurut Vanis (2007), Kondis tanah yang diperlukan untuk menghasilkan produksi yang optimal adalah tanah yang lembab, kelembaban yang dikehendaki oleh rumput gajah adalah 60$70 \%$. Tanah yang digunakan dalam penelitian tergolong jenis tanah yang cocok untuk pertumbuhan rumput raja, dimana rumput raja dapat tumbuh baik pada tanah subur serta tidak terlalu liat, $\mathrm{pH}$ tanah lebih kurang 6,5. Hasil analisis laboratorium menunjukkan bahwa $\mathrm{N}$ yang tersedia pada tanah berkisar $0,06-0,11$, $\mathrm{P}$ berkisar 1,89-5,61 dan $\mathrm{pH}$ tanah ada pada kisaran 6,8-7,58, ditambah lagi kadar $\mathrm{N}(0,30), \mathrm{P}(1,95)$ yang tersedia dalam biochar yang sangat mendukung pertumbuhan rumput raja. Hasil penelitian ini lebih tinggi dari penelitian Mufarihin et al. (2012) yang menggunakan auksin terhadap pertumbuhan rumput raja dan mendapatkan tinggi tanaman berkisar antara 71,27-97,54. Hal ini sebagai akibat dari perbedaan lingkungan eksternal seperti suhu dan kelembaban, sinar matahari dan air.

\subsection{Jumlah Daun}

Daun merupakan organ yang penting bagi tanaman dimana daun mempunyai organ yang dapat mensintesis makanan untuk kebutuhan tanaman maupun sebagai cadangan makanan. Proses yang terjadi diantaranya proses fotosintesis dimana dalam pengolahannya menggunakan sinar matahari sebagai sumber energi selain itu juga di dalam bagian daun terdapat klorofil yang akan 
berinteraksi dalam proses fotosintesis. Semakin banyak daun maka akan semakin banyak proses fotosintesis dan akan semakin banyak makanan yang diproduksi.

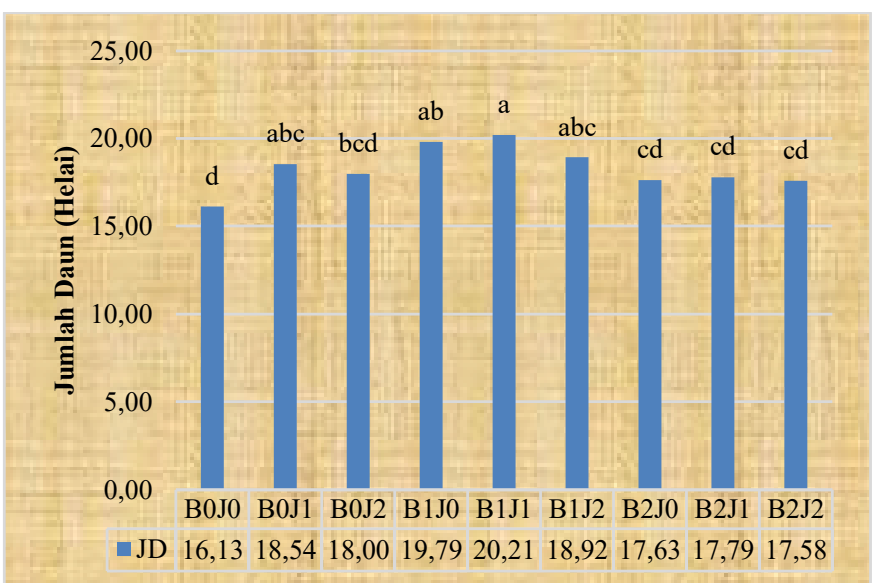

Gambar 2. Jumlah daun (Helai); Superskrip yang tidak sama menunjukkan berbeda nyata $(\mathrm{P}<0,05)$; Tidak Terjadi Interaksi Antara Faktor.

Hasil sidik ragam (Anova) menunjukkan bahwa tidak terjadi interaksi antara perlakuan dosis biochar dan jarak tanam terhadap pertumbuhan jumlah daun rumput raja. Dari Gambar 2 diatas menunjukkan bahwa jumlah daun terbaik pada tanaman yang mendapat perlakuan dosis $250 \mathrm{~g}$ dan jarak tanam $20 \mathrm{~cm}=$ 20,2.Uji duncan menunjukkan, pada pasangan perlakuan $\mathrm{B}_{0} \mathrm{~J}_{1}, \mathrm{~B}_{1} \mathrm{~J}_{2}, \mathrm{~B}_{2} \mathrm{~J}_{0}, \mathrm{~B}_{2} \mathrm{~J}_{1}$, $\mathrm{B}_{2} \mathrm{~J}_{2}$ yang tidak berbeda nyata. Penggunaan biochar $250 \mathrm{~g} / \mathrm{lubang}$ tanam dengan jarak tanam $40 \mathrm{~cm}$ memberikan efek terbaik terhadap peningkatan jumlah daun rumput raja. Pada umumnya jumlah daun lebih disebabkan karena kebutuhan hara rumput raja yang telah terpenuhi. Terpenuhinya hara ini berasal dari penambahan biochar maupun hara yang tersedia di dalam tanah sehingga proses pembentukan daun berlangsung dengan optimal. Beberapa hara yang penting dalam peningkatan jumlah daun adalah $\mathrm{N}, \mathrm{P}$ dan $\mathrm{K}$. Fosfor berperan dalam penyusunan tubuh tanaman dan beberapa koenzim yang berperan dalam aktivitas metabolisme (Hidayat, 2008). Jika aktivitas metabolisme berjalan dengan normal maka bahan organik yang tersedia akan melimpah sehingga berakibat pada penambahan jumlah daun. Sarief (1986) menyatakan bahwa P berfungsi dalam pembelahan sel, penyusunan lemak dan protein yang dapat merangsan pertumbuhan akar sehingga pembentukan daun meningkat. Hal ini sesuai pendapat (Ruhnayat, 2007), bahwa unsur nitrogen diperlukan untuk pembentukan atau pertumbuhan bagian vegetatif tanaman, seperti daun, batang dan akar. Berperan penting dalam hal pembentukan hijau daun yang berguna sekali dalam proses fotosintesis, unsur $\mathrm{N}$ berperan untuk mempercepat fase vegetatif karena fungsi utama unsur $\mathrm{N}$ itu sendiri sebagai sintesis klorofil. Klorofil berfungsi untuk menangkap cahaya matahari yang berguna untuk pembentukan makanan dalam fotosintesis, kandungan klorofil yang cukup dapat membantu atau memacu pertumbuhan tanaman terutama merangsang organ vegetatif tanaman. Pertumbuhan akar, batang dan daun terjadi dengan cepat jika persediaan makanan yang digunakan untuk proses pembentukan organ tersebut dalam keadaan atau jumlah yang cukup. Biochar yang digunakan dalam penelitian ini cukup menyediakan hara bagi kebutuhan tanaman rumput raja dengan kadar N $(0,30 \%)$, P $(1,95 \%)$ dan K $(1,32 \%)$. Sedangkan pada faktor level jarak tanam tidak memberikan pengaruh yang nyata. Hal ini lebih disebabkan karena kandungan hara yang terdapat dalam tanah yang berasal dari biochar dapat menunjang pertumbuhan sehingga kompetisi antar tanaman berkurang.

\subsection{Jumlah Anakan}

Jumlah anakan merupakan salah satu bagian yang menunjukkan pertumbuhan dan perkembangan tanaman pada fase vegetatif. Jumlah anakan dapat digunakan umtuk menduga tinggi rendahnya bobot hijauan yang dihasilkan. Jumlah anakan yang terdapat di setiap steknya dipengaruhi oleh beberapa hal, diantaranya karena adanya faktor-faktor pembatas dari pertumbuhan.

Hasil penelitian menunjukkan bahwa jumlah anakan terbanyak pada perlakuan $\left(\mathrm{B}_{0} \mathrm{~J}_{2}\right)=12,25$ dan jumlah anakan yang sedikit ada pada perlakuan $\left(B_{2} J_{2}\right)=9,04$. Hasil sidik ragam (Anova) menunjukkan bahwa tidak terjadi interaksi antara perlakuan dosis biochar dan jarak tanam terhadap jumlah anakan rumput raja. Dari Gambar 3 menunjukkan bahwa pada perlakuan dosis biochar dan jarak tanam memperlihatkan jumlah anakan terbanyak ditunjukkan pada tanaman yang mendapat perlakuan $\mathrm{B}_{0} \mathrm{~J}_{2}$ dibandingkan $\mathrm{B}_{0} \mathrm{~J}_{0}, \mathrm{~B}_{0} \mathrm{~J}_{1}, \mathrm{~B}_{1} \mathrm{~J}_{0}, \mathrm{~B} 1_{1} \mathrm{~J}_{1}, \mathrm{~B}_{1} \mathrm{~J}_{2}$, $\mathrm{B}_{2} \mathrm{~J}_{0}, \mathrm{~B}_{2} \mathrm{~J}_{1}$ dan $\mathrm{B}_{2} \mathrm{~J}_{2}$. Rismunandar (1986) menyatakan bahwa jumlah anakan rumput raja berkisar 20-50 anakan sedangkan penelitian Jamaran (2006) mendapatkan jumlah anakan sebanyak 40,00-48,66 anakan. Perbedaan jumlah anakan ini lebih disebabkan karena perbedaan lingkungan dan perlakuan yang diberikan. Uji duncan menunjukkan pasangan perlakuan yang tidak berbeda $B_{0} J_{1}$ dan $\mathrm{B}_{0} \mathrm{~J}_{2}$ di ikuti $\mathrm{B}_{1} \mathrm{~J}_{0}, \mathrm{~B}_{1} \mathrm{~J}_{1}$, dan $\mathrm{B}_{1} \mathrm{~J}_{2}$ di ikuti $\mathrm{B}_{2} \mathrm{~J}_{0}, \mathrm{~B}_{2} \mathrm{~J}_{1}$, dan $\mathrm{B}_{2} \mathrm{~J}_{2}$ yang tidak berbeda nyata.

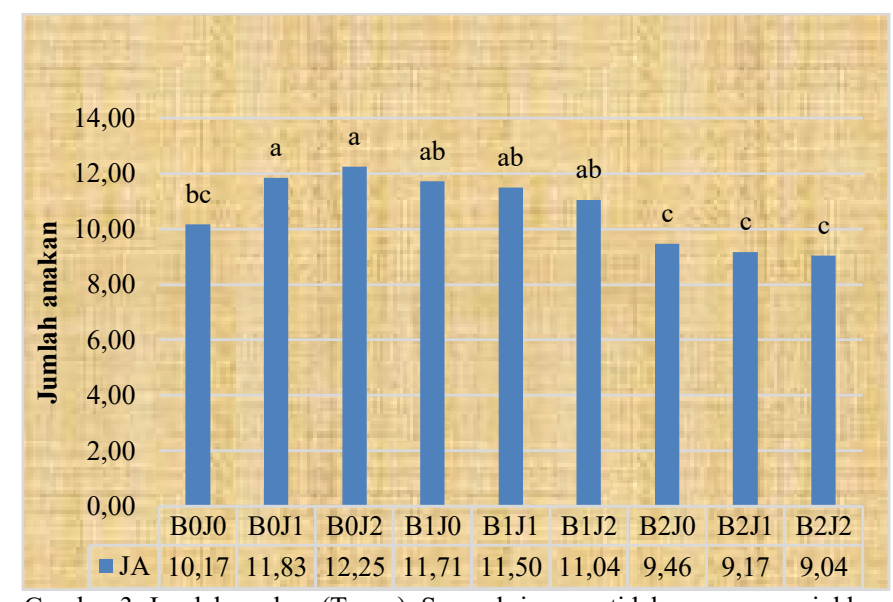

Gambar 3. Jumlah anakan (Tunas); Superskrip yang tidak sama menunjukkan berbeda nyata $(\mathrm{P}<0,05)$; Tidak Terjadi Interaksi Antara Faktor.

\subsection{Berat Segar dan Kering Daun}

Berat segar tanaman merupakan berat kesuluruhan tanaman setelah panen dan sebelum tanaman mengalami layu akibat kehilangan air. Berat segar tanaman merupakan parameter untuk mengetahui biomasa dari pertumbuhan tanaman. Biomassa tanaman merupakan suatu ukuran hasil dari pertumbuhan tanaman yang dihasilkan dari reaksi-reaksi biokimia yang diawali dari penyusunan sel-sel yang akan membentuk jaringan kemudian akan membangun organ hingga pada akhirnya membentuk tubuh tanaman. Menurut Sitompul dan Guritno (1995) bahwa biomassa tanaman meliputi semua bahan tanaman yang secara kasar, berasal dari hasil fotosintesis, serapan unsur hara dan air yang diolah melalui proses biosintesis.

Berat kering tanaman merupakan parameter pengamatan yang digunakan untuk mengetahui kandungan biomasa dan air yang terkandung pada tanaman. Berat kering tanaman dilakukan pengamatan dengan cara menimbang berat segar tanaman terlebih dahulu setelah diketahui berat segar tanaman kemudian dilakukan pengeringan hingga kadar air yang terkandung hilang kemudian dilakukan penimbangan. Pengeringan yang berlangsung pada umumnya dilakukan dengan temperatur berkisar $75^{\circ} \mathrm{C}$.

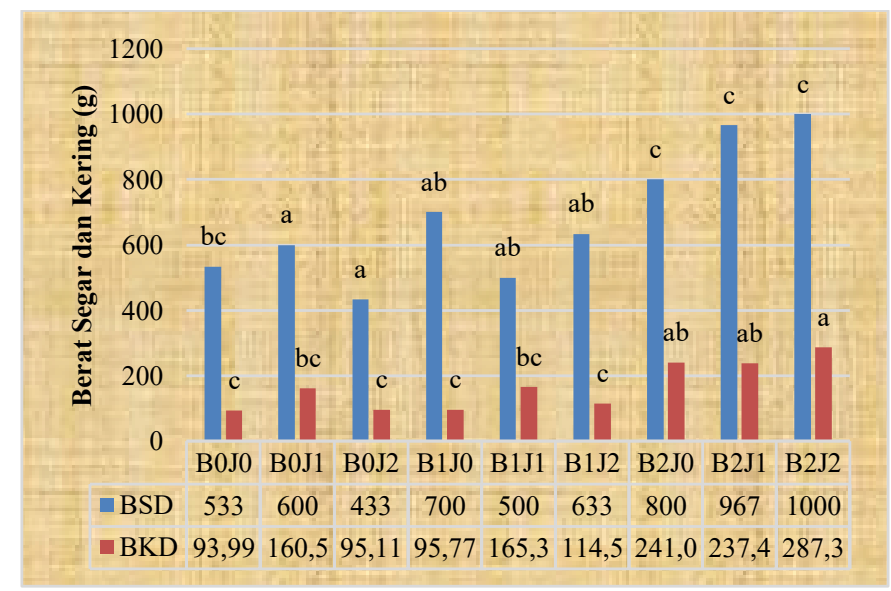

Gambar 4. Berat Segar dan Kering Daun (g); Superskrip yang tidak sama menunjukkan berbeda nyata $(\mathrm{P}<0,05)$.

Berat segar daun merupakan salah satu parameter yang dapat mewakili pertumbuhan tanaman. Semakin besar berat segar daun berarti semakin banyak biomasa yang dihasilkan, dalam hal ini tentunya berkaitan dengan jumlah unsur hara yang tersedia di tanah. Hasil sidik ragam (Anova) menunjukkan bahwa tidak terjadi interaksi antara perlakuan dosis biochar dan jarak tanam terhadap bobot segar dan kering daun. Dari Gambar 4 menunjukkan bahwa pada pasangan perlakuan berat segar daun yang tidak berbeda $\mathrm{B}_{0} \mathrm{~J}_{1}$ dan $\mathrm{B}_{0} \mathrm{~J}_{2}$ diikuti $\mathrm{B}_{1} \mathrm{~J}_{0}, \mathrm{~B}_{1} \mathrm{~J}$ dan $B_{1} J_{2}$ diikuti $B_{2} J_{0}, B_{2} J_{1}$, dan $B_{2} J_{2}$, pada pasangan perlakuan berat kering daun yang tidak berbeda $B_{0} J_{1}$ dan $B_{0} J_{2}$ di ikuti $B_{1} J_{0}, B_{1} J_{1}$, dan $B_{1} J_{2}$ di ikuti $B_{2} J_{0}$ dan $\mathrm{B}_{2} \mathrm{~J}_{1}$. Berat kering daun merupakan salah satu kriteria dalam mengetahui laju pertumbuhan tanaman dengan bertambahnya berat kering daun pada tanaman Hasil sidik ragam (Anova) menunjukkan bahwa tidak terjadi interaksi antara perlakuan dosis biochar dan jarak tanam terhadap bobot kering daun. Dari Gambar 4 menunjukkan bahwa pada perlakuan $\mathrm{B}_{2} \mathrm{~J}_{2}$ memperlihatkan berat kering daun terbaik dibandingkan $\mathrm{B}_{0} \mathrm{~J}_{0}, \mathrm{~B}_{0} \mathrm{~J}_{1}, \mathrm{~B}_{0} \mathrm{~J}_{2} \mathrm{~B}_{1} \mathrm{~J}_{0}, \mathrm{~B}_{1} \mathrm{~J}_{1}, \mathrm{~B}_{1} \mathrm{~J}_{2}, \mathrm{~B}_{2} \mathrm{~J}_{0}$ dan $\mathrm{B}_{2} \mathrm{~J}_{1}$. Gambar 4 menunjukkan bahwa jarak tanama yang semakin jauh akan menghasilkan berat segar dan berat kering yang lebih tinggi. Jarak tanam mempengaruhi tinggi rendahnya hasil tanaman, sehingga tinggi rendahnya hasil tanaman mempengaruhi produksi dalam satu areal (Istikomah dan Kunharjanti, 2017). Dilanjutkan oleh Jasmaran (2006) bahwa jarak tanam yang sangat sempit akan menghasilkan rumput yang lebih banyak sehingga produksi bahan kering akan 
turun. Hal ini membuktikan bahwa jarak tanam akan sangat mempengaruhi berat kering dan segar daun dan hal ini juga dipengaruhi oleh ketersediaan hara, cahaya matahari dan ketersediaan air.

\section{Simpulan}

Level biochar dalam peningkatan pertumbuhan rumput raja bervariasi, untuk tinggi tanaman dan jumlah anakan tanpa menggunakan biochar masih dapat bertumbuh secara optimal sedangkan untuk peningkatan jumlah daun pada penggunaan level $250 \mathrm{~g} /$ lubang tanam. Level $500 \mathrm{~g} / \mathrm{lubang}$ tanam efektif dalam meningkatkan berat kering dan berat segar daun rumput raja.

Jarak tanam terbaik pada pertumbuhan dan produksi rumput raja bervariasi untuk tinggi tanaman dan jumlah anakan jarak tanam terbaik adalah $20 \mathrm{~cm}$ sedangkan untuk peningkatan jumlah daun terbanyak pada jarak tanam 40 $\mathrm{cm}$. Jarak tanam $60 \mathrm{~cm}$ efektif dalam meningkatkan berat kering dan berat segar daun rumput raja. Tidak terjadi interaksi antara level biochar dan jarak tanam pada semua variabel pengamatan.

\section{Pustaka}

Djaenudin D. 2007. Potensi Sumber Daya Lahan untuk Perluasan Areal Tanaman Pangan di Kabupaten Merauke. Jurnal Iptek Tanaman Pangan. 2(2): $180-194$.

Gani, A. 2009. Biochar Penyelamat Lingkungan. Warta Penelitian dan Pengembangan Pertanian, 31 (6) : 15-16.

Hidayat, N. 2008. Pertumbuhan dan produksi kacang tanah (Arachis hypogea L.) varietas lokal madura pada berbagai jarak tanam dan jarak tanam dan dosis pupuk fosfor. Agrovigor, 1(1) 55-64.

Istikomah, N dan A. W. Kunharjanti. 2017. Perbedaan Jarak Tanam Terhadap Produktivitas Defoliasi Pertama Rumput Mott (Pennisetum purpureum cv. Mott). Jurnal Aves, 11 (2) : 14-21.

Jamaran, N. 2006. Produksi dan kandungan gizi rumput gajah (P. Purpureum) dan rumput raja (P.purpupoides) yang ditumpangsarikan dengan tanaman jati. Jurnal Peternakan Indonesia, 11 (2) 151-157.

Mufarihin, A., D.R.Lukiwati dan Sutarno. 2012. Pertumbuhan dan bobot kering rumput gajah dan rumput raja pada perlakuan aras auksin yang berbeda. Animal agriculture journal, 1 (2) 1-15.

Rismunandar. 1986. Mendayagunakan tanaman rumput. Sinar baru, Bandung.

Ruhnayat, A. 2007. Penentuan Kebutuhan Pokok Unsur Hara N, P, K untuk Pertumbuhan Tanaman Panili (Vanilla planifolia). Jakarta :Balai Penelitian Tanaman Obat dan Aromatik. Buletin Littro, 18 (1 ) : 49 - 59.

Sarief, S. 1986. Kesuburan dan Pemupukan Tanah Pertanian. Pustaka Buana. Bandung

Steiner, C., W.G. Teixeira, J. Lehmann, T. Nehls, J,L.V. de Macedo, W,E.H. Blum, W. Zech. 2007. Long termeffects of manure, charcoal and mineral fertilization on crop production and fertility on a highly weathered central Amazonian upland soil. Plant and soil, 291: 275- 290.

Sitompul, S.M dan B. Guritno. 1995. Analisis PertumbuhanTanaman. Gadjah Mada University Press. Yogyakarta.

Suyitman. 2014. Produktivitas Rumput Raja (Pennisetum purpupoides) pada Pemotongan Pertama Menggunakan Beberapa Sistem Pertanian. Jurnal peternakan Indonesia, 16 (2) : 119-127.

Vanis, D. R. 2007. Pengaruh Pemupukan dan Interval Defoliasi Terhadap Pertumbuhan Dan Produktivitas Rumput Gajah (Pennisetum purpureum) di bawah tegakan pohon segon (Paraserianthes falcataria). [Skripsi] Fakultas Perternakan Institut Pertanian Bogor. 